\title{
MIKROKAPCSOLÓK ÉLETTARTAMÁNAK VIZSGÁLATA
}

\author{
Sipkás Vivien - Vadászné Bognár Gabriella
}

Absztrakt: A vizsgált mikrokapcsolók meghibásodási analízise során a gyorsított élettartam vizsgálati módszert kívánjuk alkalmazni. A tesztsorozatok eredményeinek elemzésekor meghatározzuk az ún. Weibull-eloszlás paramétereit és vizsgáljuk a tönkremeneteli és meghibásodási folyamatok hatását a mikrokapcsolók élettartamára vonatkozóan.

\begin{abstract}
The accelerated lifetime testing method is used for the investigation of the failure analysis of the micro switches. During the examination, the determination of the parameters of the Weibull distribution is carried out and the effect of the failure methods is analysed for the lifetime of the micro switches.
\end{abstract}

\section{Bevezetés}

Az élettartam elemzések magukba foglalják a technológiai vizsgálatokat, az anyagés kopásvizsgálatok különböző területeit, mivel a vizsgálat végkimenetelére csak a tényleges élettartam végén kaphatunk választ, egy adott termék folyamatos nyomon követésével. A gyorsított élettartam vizsgálatok elönye az, hogy statisztikailag is megbízható élettartam adatokat viszonylag rövid tesztelési idő alatt lehet meghatározni. Az említett vizsgálati módszer közös jellegzetessége, hogy valamely élettartamot meghatározó tényezőt fokozott mértékben vizsgáljuk, mint például megemelt igénybevételi gyakoriság, sebesség változás, terhelési szintemelkedés és csökkenés és környezeti hatások (Gregász, 2009).

A gyorsított élettartam vizsgálatok (Acceleratad Life Testing) során a Waloddi Weibull által 1951-ben bevezetett ún. Weibull-eloszlást alkalmazzuk. Ez egy valószínüségszámítási elméleten alapuló elemzés, melyben folytonos valószínüség eloszlást vizsgálunk. Az általunk vizsgálandó mikrokapcsolók meghibásodásainak analízise során a tesztsorozatok eredményeinek elemzésében ezen eloszlás alkalmazásával elemezzük a különböző tönkremeneteli és meghibásodási folyamatok hatását a mikrokapcsolók élettartamára vonatkozóan.

\section{A mikrokapcsolók meghibásodásának gyakoribb esetei}

A mikrokapcsolók a villamos áramkört üzem közben nyitó, valamint záró érintkezős készuilékelemek. Használat során a kapcsolóknak nagyszámú megszakítás-zárás ciklust kell végezniük, ezért élettartamukat elsősorban az anyagvándorlás, az érintkezők kopása befolyásolja és határozza meg. Az utóbbi években a kapcsolók nagymértékü miniatürizáláson mentek keresztül. Megbízhatóságuk nagymértékben megnövekedett, igazodva az aktív és passzív elemek hosszú élettartamához. Egy kapcsolónak manapság $10^{4} \ldots 10^{6}$ számú hibamentest kapcsolást kell teljesíteni.

A kapcsoló érintkezőinek mủködése, vagyis az áramkör zárása és megszakítása közben ív jöhet létre és ez az érintkezők méretezését és alkalmazhatóságát és élettartamát befolyásolja (Mojzes, 2005)

A mikrokapcsolóknak számos meghibásodási esete fordul elö, ezek közül csak néhányat szeretnénk megemlíteni. A hálózatról müködtetett kerti gépek esetében a 
szabvány szerint egy mikrokapcsolónak $50 \cdot 10^{3}$ kapcsolást, míg akkumulátoros gépek esetén $6 \cdot 10^{3}$ kapcsolási ciklust kell hibamentesen kibírnia.

A mikrokapcsolók egyik leggyakoribb problémája a magas hőmérsékletből adódó deformáció. Ennek több oka is lehet, egyrészt túlterhelésből adódó, másrészt a kapcsolók megengedettnél magasabb számú kapcsolgatásából bekövetkező túlmelegedés. Az áramkör zárása és megszakítása közben ív jön létre, ennek következménye, az anyagvándorlás, a hőképződés és az átmeneti ellenállás megnövekedése, így a kapcsolóval érintkező alkatrészek átmelegedhetnek, valamint a kapcsolóban lévő előfeszített alkatrészek, (például rugó) túlmelegedés következtében kilágyulhatnak. További meghibásodási probléma, amikor a kapcsolón az előírtnál nagyobb áram folyik, illetve zárlat esetén a konstrukció szét is éghet, a kapcsolóban lévő laprugó deformálódhat, elveszítheti rugalmasságát és ezzel eredeti funkciója megszünik, ezért a gépet nem lehet ki- vagy bekapcsolni.

$\mathrm{Az}$ érintkezők között kialakuló sztatikus ívkisülés által okozott anyagveszteség is elöfordulhat. Az elektromos, termikus és mechanikus igénybevételeknek következtében egy bizonyos kapcsolási szám felett az érintkező az összehegedés következtében is meghibásodhat.

Másik jellemző meghibásodási probléma a mikrokapcsoló kapcsológombjának a kopása, amely adódhat rossz konstrukciós kialakításból, a nem megfelelő anyagválasztásból, gyártási hibákból, de a müködtetés közbeni oldalirányú nyomóterhelésböl és a magas kapcsolási számtól is. Mindezen hibaokok közös következményeképpen az alkatrész megkophat és eltörhet.

\section{A fürdőkád-görbe}

A meghibásodás gyakoriságát az idő paraméter függvényében ábrázoló jelleggörbét jellegzetes alakja miatt „fürdőkád-jelleggörbének” nevezik. Három jellegzetes, egymást követő tartománya van: I. a korai meghibásodások, II. a véletlen meghibásodások, illetve III. az elhasználódásból adódó meghibásodások tartománya. A biológia területén is hasonló jellegzetességeket lehet megfigyelni: a csecsemőkori halandóság, a felnőttek normális halálozási gyakorisága balesetek és fertőzések következtében, valamint az idöskori elhalálozás. A fürdőkád görbét szemléltetik az 1-2. ábrák, melyek a gépkocsi és a jelfogó mágneskapcsoló meghibásodási gyakoriságát mutatják a jellemző befolyásoló tényezők függvényében (Schaefer, 1983) 


\section{1-2. ábra: A fürdőkád-görbék mágneskapcsolók meghibásodása a} kapcsolási szám függvényében és gépkocsik meghibásodása esetén a megtett km függvényében
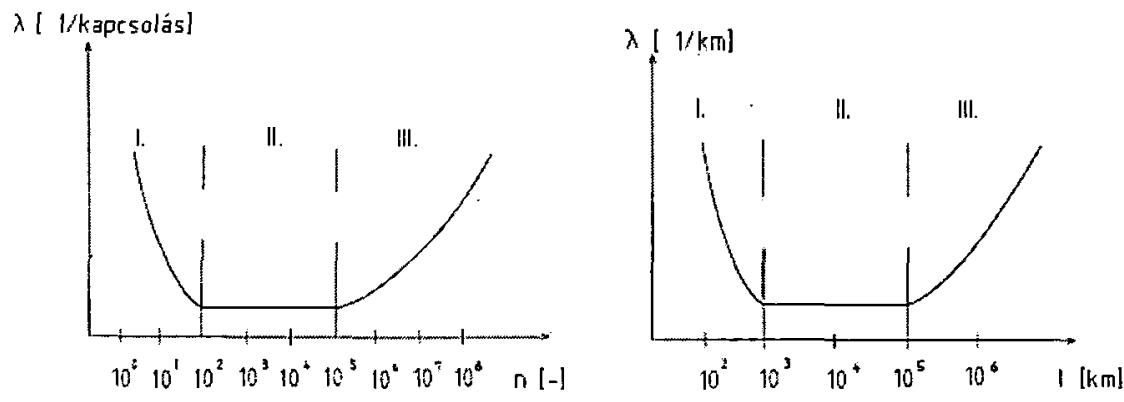

Forrás: A szerző saját szerkesztése (Schaefer, 1983) alapján. /Sipkás V. (2017)

\section{A Weibull-eloszlás}

Waloddi Weibull (1887-1979) svéd mérnök által az 1940-es években, anyagfáradással . kapcsolatos kérdésekkel összefüggésben az időfüggő meghibásodási gyakoriságot egy speciális hatványfüggvénnyel közelítette. Ezzel olyan eloszlást adott meg, amely teljes körüen használható az élettartam vizsgálatával kapcsolatban. Az exponenciális eloszlás a Weibull-eloszlásnak egy speciális esete, mellyel a meghibásodások korai szakasza jellemezhető.

A Weibull-eloszlás általános, háromparaméteres alakjával az eloszlásfüggvényt a következőképpen írhatjuk fel (Balogh-Dukáti, 1972)

$$
F(t)=\left\{\begin{array}{rr}
1-\exp \left[-\frac{(t-\gamma)^{\beta}}{\alpha}\right], & \text { ha } t \geq \gamma, \\
0, & \text { ha } t<\gamma .
\end{array}\right.
$$

Az $F(t)$ függvény megadja a $t$ tényleges müködési idő alatti meghibásodási valószínüséget, azaz a selejtarányt. Az (1) képletben $t$ a statisztikus változó (az idő órákban vagy a müködtetések száma)

$\alpha>0$ a skalárparaméter,

$\beta>0$ az alakparaméter,

$\gamma \geq 0$ a helyparaméter.

Az $\eta$ a mértékparaméter, vagy karakterisztikus élettartam. Vezessük be az $\eta=$ $\alpha^{1 / \beta}$ helyettesítést az (1) kifejezésbe. Így az előzőekben felírt eloszlásfüggvény alakja:

$$
F(t)=\left\{\begin{array}{rr}
1-\exp \left[-\left(\frac{t-\gamma}{\eta}\right)^{\beta}\right], & \text { ha } t \geq \gamma \\
0, & \text { ha } t<\gamma .
\end{array}\right.
$$


A $\gamma$ helyparaméter a gyakorlati alkalmazásoknak csak kis részében egyenlő 0 val, a mintavételi terveket mégis a $\gamma=0$ esetre adják meg. A $\beta$ alakparaméter értéke a sürüségfüggvény alakját határozza meg. A Weibull-eloszlás sürüségfüggvénye $\gamma=$ 0 esetben az (1a) képletböl differenciálással határozható meg (lásd 3. ábra).

$$
f(t)=F^{\prime}(t)=\left\{\begin{array}{c}
\frac{\beta}{\eta}\left(\frac{t}{\eta}\right)^{\beta-1} \exp \left[-\left(\frac{t}{\eta}\right)^{\beta}\right], \text { ha } t \geq 0 \\
0, \\
\text { ha } t<0 .
\end{array}\right.
$$

Ha $\beta<1$, akkor az $f(t)$ monoton csökkenő függvény, ez a korai meghibásodások szakaszát jelöli.

Ha $\beta=1$, akkor az exponenciális eloszlást kapjuk, ez a véletlen meghibásodások szakasza.

Ha $\beta>1$, akkor a sürüségfüggvénynek maximum helye van, ez az elhasználódással összefüggö meghibásodások szakaszára jellemző.

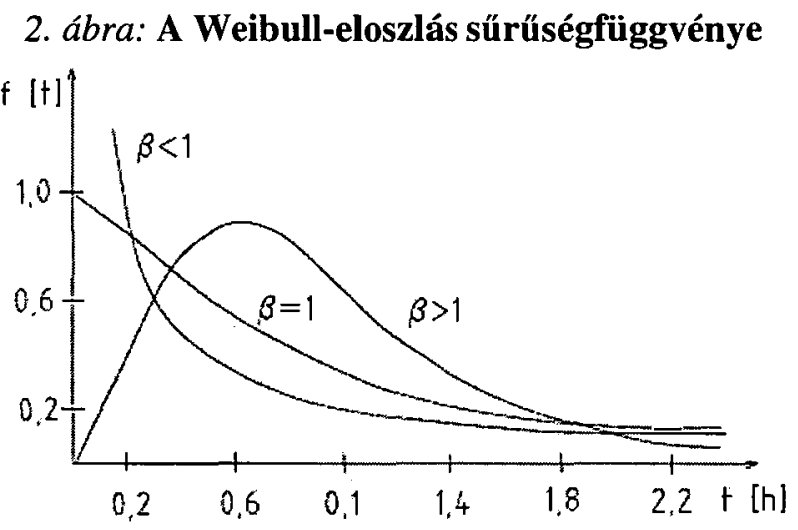

Forrás: A szerző saját szerkesztése (Balogh-Dukáti, 1972) alapján. /Sipkás V. (2017)

A Weibull-eloszlás esetében a meghibásodási ráta, vagy meghibásodási gyakoriság az idő függvényében $\gamma=0$ esetén a következő:

$$
\lambda=\frac{f(t)}{1-F(t)}= \begin{cases}\frac{\beta}{\eta}\left(\frac{t}{\eta}\right)^{\beta-1} & , \text { ha } t \geq 0 \\ 0, & \text { ha } t<0 .\end{cases}
$$

Megjegyezzük, hogy a Weibull-eloszlás esetében a várható tényleges müködés $\gamma=0$ értékhez tartozik. Ha $\beta<1$, akkor $\lambda(t)$ monoton csökkenő, ha $\beta=1$, akkor $\lambda(t)=$ állandó, ez az exponenciális eloszlás esete, azonban, ha $\beta>1$, akkor $\lambda(t)$ monoton növekvő függvény (lásd 4. ábra). A Weibull-eloszlásnál a várható tényleges müködés $\gamma=0$ értékre a következöképpen írható fel: 


$$
\begin{gathered}
\mu=E(\tau)=\int_{0}^{\infty} t f(t) d t=\int_{0}^{\infty} t \frac{\beta}{\eta}\left(\frac{t}{\eta}\right)^{\beta-1} \exp \left[-\left(\frac{t}{\eta}\right)^{\beta}\right] d t \\
=\eta \Gamma\left(1+\frac{1}{\beta}\right)=\alpha^{\frac{1}{2}} \Gamma\left(1+\frac{1}{\beta}\right)
\end{gathered}
$$

3. ábra: Weibull-eloszlás esetén a meghibásodási ráta függvénye $\gamma=0$ és $\Gamma$ a gamma függvény $\boldsymbol{\eta}=\mathbf{1}$ esetén

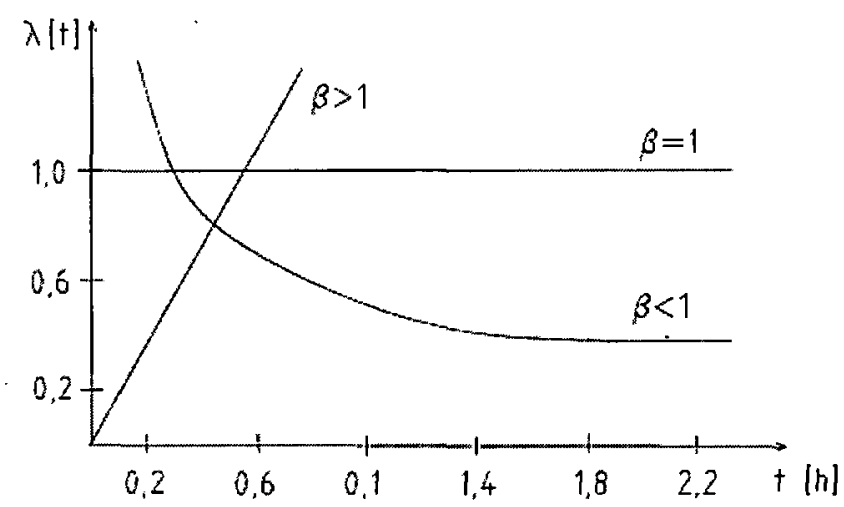

Forrás: A szerző saját szerkesztése (Balogh-Dukáti, 1972) alapján. /Sipkás V. (2017)

A diagram alapján megállapíthatjuk a három szakasz jellemzőit:

\subsection{Korai meghibásodások (early failures)}

A korai meghibásodások szakaszában a meghatározó meghibásodási gyakoriság az idővel csökken $(\beta<1)$. A müszaki termékek esetében az volna az ideális, ha a korai meghibásodások szakaszának befejezése időben egybeesne a gyártóüzemi vizsgálatok befejezésével.

4.2.Véletlen meghibásodások (random failures)

A véletlen meghibásodások szakaszában a meghibásodási gyakoriság az időtől független (állandó). A Weibull-kitevő egységnyi értékü $(\beta=1)$.

\subsection{Elhasználódási meghibásodások (wearout failures)}

A görbének ebben a szakaszában a meghibásodási gyakoriság az idövel növekszik. Ezt az időtartományt az elhasználódási jelenségek következtében gyakoribbá váló meghibásodások jellemzik, ekkor a Weibull-kitevő $\beta>1$. Mivel a meghibásodások ebben a szakaszban egyre gyakoribbá válnak, ebben az időszakban az elhasználódásnak kitett alkatrészeket fel kell újítani (Schaefer, 1983) 


\section{Mintavételi eljárások}

A mintavételi eljárások két csoportra oszthatóak:

- várható tényleges müködésre vonatkozó követelmény ellenőrzésére szolgáló eljárás,

- meghibásodási rátára vonatkozó követelmény ellenőrzésére irányuló eljárás.

Minkét esetben $\beta$-t ismeretlennek tételezzük fel, a mintavételi eljárás lépései azonosak (Balogh-Dukáti, 1972):

a) Kiválasztunk a tételből egy $n$ elemü mintát.

b) A mintán elöre megadott $t$ ideig végezzük el a tényleges müködés vizsgálatát. Adott esetben a vizsgálat nemcsak idötartammal, hanem másként is elő lehet írva (pl. indítási vagy kapcsolási ciklusokkal)

c) Megfigyeljük a $t$ ideig bekövetkezett meghibásodások $r$ számát.

d) A tételt átvesszük, ha $r \leq c$ (ahol c egy előre megadott átvételi szám), és a tételt visszautasítjuk abban az esetben, ha $r>c$.

\section{Meghibásodási gyakoriságok meghatározása}

Az élettartam meghatározása szempontjából az egyik legfontosabb paraméter a $\lambda$ meghibásodási gyakoriság. Ennek reciproka az $m$ átlagos élettartam a véletlen meghibásodások időszakában. A Weibull-eloszlás $\eta$ karakterisztikus élettartama 1 és 2,5 közötti $\beta$ értékek esetén közelítöleg az $m$ értékkel egyezik meg. Minden alkatrészre jellemző egy $\lambda$ érték, amely az alkatrészre vonatkozó meghibásodási mechanizmusból is adódhat. A $\lambda$ értéket az alábbi egyenletet felhasználva lehet meghatározni (Schaefer, 1983)

ahol:

$$
\lambda \approx \frac{c}{N \Delta t}
$$

$c$ a meghibásodáshoz vezetô hibák száma, $\Delta t$ a vizsgálati idő, $N$ a próba darabszáma.

A meghibásodásként csak névleges igénybevételnél bekövetkező meghibásodásokat szabad figyelembe venni, az elektromos, termikus, mechanikus vagy vegyi jellegü fokozott igénybevételekből származó meghibásodásokat nem.

\section{Gyorsított vizsgálatok}

A meghibásodási gyakoriság meghatározásához egy adott alkatrészcsoportot névleges terhelésen, határadatokkal kell terhelni és szükséges kivárni a meghibásodásokat. Az ilyen vizsgálati követelmények a gyártás ellenörzésére alkalmatlanok. Ezért az igénybevételek növelésével a vizsgálati idő rövidítésére törekszenek. Ezzel kapcsolatban a következő kérdések merülnek fel:

- Milyen gyorsítási módszerek valósíthatók meg?

- Az alkatrész milyen megnövelt igénybevétele engedhető meg? 
A 4. ábrából adódóan megállapítható, hogy gyorsított vizsgálatoknál (A pont) a vizsgálati idő állandó, és a terhelést fokozatokban változtatják. Ezután a meghibásodásokat megszámolják és osztályokba sorolják, elkülönítik, majd feljegyzik. A $B$ ponton leolvasható tartós vizsgálatoknál a terhelés állandó. Egymást követő időszakokban megszámolják a meghibásodásokat és azok számát hisztogramban rögzítik és ezt követően a kapott adatokat üzemi alkalmazásra $(C)$ átszámítjuk. Ennél a pontnál kis igénybevétel, de hosszú vizsgálati idő jellemző (Schaefer, 1983)

\section{4. ábra: Igénybevétel-idődiagram változatlanul maradó meghibásodás-eloszlás esetén}

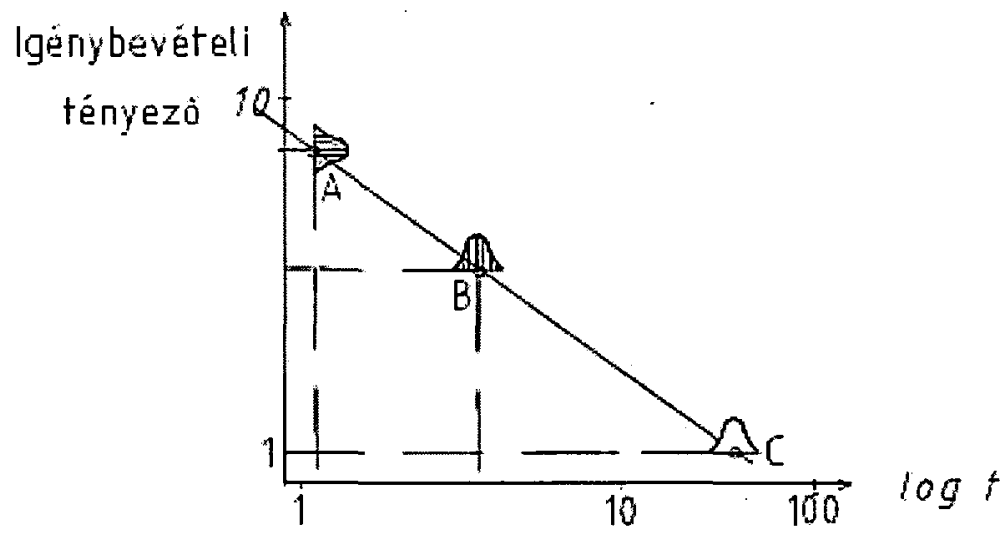

Forrás: A szerző saját szerkesztése (Schaefer, 1983) alapján. /Sipkás V. (2017)

\section{8. Összefoglalás}

$\mathrm{Az}$ irodalomkutatás és Weibull-eloszlás matematikai modelljének megismerését követően a kutatás következő állomása a vizsgálandó mikrokapcsolók tesztelésére alkalmas munkapad megtervezése és összeállítása, ezt követően pedig mérési paraméterek meghatározása. Továbbiakban pedig a tesztelések elvégzése, kiértékelés és adatok összegyüjtése a további célunk; ezek elvégzését követően a numerikus elemzések a gyorsított élettartam meghatározáshoz.

\section{Köszönetnyilvánítás}

A cikkben ismertetett kutató munka az EFOP-3.6.1-16-2016-00011 jelü „Fiatalodó és Megújuló Egyetem - Innovatív Tudásváros - a Miskolci Egyetem intelligens szakosodást szolgáló intézményi fejlesztése" projekt részeként - a Széchenyi 2020 keretében - az Európai Unió támogatásával, az Európai Szociális Alap társfinanszírozásával valósul meg.

\section{Irodalomjegyzék}

Balogh A., Dukáti F. (1972): Megbízhatósági vizsgálatok Weibull-eloszláson alapuló mintavételi eljárásai és tervei, Híradástechnika, 24 (1): 1-8. 
Gregász Tibor (2009): Nemfémes szerkezeti anyagok élettartam-problémáinak minőségügyi megközelítése. PhD értekezés. Nyugat-magyarországi Egyetem, Sopron.

Jayatilleka, S., Okogbaa, G. (2014): Accelerated Life Testing. Workshop on Accelerated Stress Testing and Reliability Conference, Saint Paul, Minnesota 55101, Egyesült Államok, 1-77. <http://www.asqrd.org/wp-content/uploads/ 2014/09/Accelerated-Life-Test-Tool-for-SpeedierProdudct-Development.pdf $>$ (2017.10.02)

Mojzes I. (2005): Mikroelekronika és technológia. Müegyetemi Kiadó, Budapest.

Schaefer, E. (1983): Megbizhatóság az elektronikában. Müszaki Könyvkiadó, Budapest. 